\title{
Optimalisasi Pemberdayaan Masyarakat melalui Strategi Pelatihan C-E-R-A-M-A-H sebagai Upaya Pengendalian Penyakit Hipertensi di Komunitas
}

\author{
Linda Widyarani, Cecilya Kustanti \\ Program Studi DIII Keperawatan, STIKES Notokusumo Yogyakarta \\ Email : lindawidyarani@gmail.com
}

\begin{abstract}
Abstrak
Hipertensi dikenal sebagai silent killer karena sering tidak disadari oleh penyandangnya dan saat diketahui sudah terjadi komplikasi. Pengukuran dan pemantauan tekanan darah di rumah secara rutin merupakan hal yang wajib dilakukan, baik bagi penderita hipertensi maupun masyarakat sebagai upaya deteksi dini dan mencegah hipertensi tidak terkontrol. Tujuan kegiatan pengabdian kepada masyarakat ini adalah meningkatkan pengetahuan dan ketrampilan kader kesehatan posyandu dan juga penderita hipertensi beserta keluarganya tentang pengukuran tekanan darah di rumah. Kegiatan pengabdian kepada masyarakat ini dilakukan pada Bulan Agustus-September Tahun 2020 di Desa Wukirsari, Imogiri, Bantul, Yogyakarta. Metode yang digunakan adalah ceramah dan praktik, dengan media yang digunakan berbentuk booklet, alat spignomanometer dan stetoskop. Hasil dari kegiatan pengabdian kepada masyarakat ini, berdasarkan hasil pretest dan posttest yang dilakukan, terdapat peningkatan pengetahuan dan ketrampilan penderita hipertensi beserta keluarganya sebesar $\pm 34,95 \%$, terjadi peningkatan dari $\pm 47,81 \%$ menjadi $\pm 82,76 \%$. Selain itu, pengetahuan dan ketrampilan kader kesehatan posyandu juga meningkat sebesar $\pm 43,77 \%$, terjadi peningkatan dari $\pm 43,69 \%$ menjadi $\pm 87,46 \%$. Pelatihan C-E-R-A-M-AH dapat dijadikan sebagai program rutin dan berkala di masyarakat sehingga angka kejadian hipertensi dalam diminimalkan dan bahaya serta komplikasi akibat hipertensi dapat dicegah.
\end{abstract}

Kata kunci : Hipertensi, Pengukuran Tekanan Darah, Kader Kesehatan

\begin{abstract}
Hypertension is called a "silent killer". Most people with hypertension are unaware of the problem because it may have no warning signs or symptoms. For this reason, it is essential that blood pressure is measured regularly. The objectives of this activity were to improve hypertensive sufferers and family's and also health cadres knowledge and skill about blood pressure measurement at home. This activity was conducted from August to September 2020 in Desa Wukirsari, Imogiri, Bantul, Yogyakarta. The methods used in this activity was training and counseling with practice, and media used was booklet C-E-R-A-M-A-H, spignomanometer and stethoscope. The result showed that the average hypertensive sufferers and family's knowledge and skills score experienced an increase, $\pm 34,95 \%$, increase from $\pm 47,81 \%$ to $\pm 82,76 \%$. The result also showed that the average health cadres knowledge and skill score about blood pressure measurement at home experienced an increase, $\pm 43,77 \%$, increase from $\pm \pm 43,69 \%$ to $\pm 87,46 \%$. This activity concluded that there was an effect of booklet C-E-R-A-M-A-H on increasing hypertensive sufferers and family's and also health cadres knowledge and skill about blood pressure measurement at home. This activity can be used as a routine and periodic program in the community so that the incidence of hypertension is minimized and the dangers and complications due to hypertension can be prevented.
\end{abstract}

Keyword : Hypertension, Blood Pressure Measurement, Health Cadres

http://ejournal.urindo.ac.id/index.php/PAMAS

Article History :

Submitted 08 Januari 2021, Accepted 26 Oktober 2021, Published 31 Oktober 2021 
Jurnal Pelayanan dan Pengabdian Masyarakat (PAMAS)

\section{PENDAHULUAN}

Penyakit jantung dan pembuluh darah (kardiovaskuler) merupakan masalah kesehatan utama di negara maju maupun negara berkembang dan menjadi penyebab kematian nomor satu di dunia setiap tahunnya. Hipertensi merupakan salah satu penyakit kardiovaskuler yang paling umum dan paling banyak diderita oleh masyarakat. Hipertensi disebut sebagai silent killer karena sering tanpa keluhan, sehingga penderita tidak mengetahui dirinya menyandang hipertensi dan baru diketahui setelah terjadi komplikasi. Kerusakan organ target akibat komplikasi hipertensi akan tergantung pada besarnya peningkatan tekanan darah yang tidak terdiagnosis dan tidak diobati. Organ-organ tubuh yang menjadi target antara lain otak, mata, jantung, ginjal dan dapat juga berakibat kepada pembuluh darah arteri perifer ${ }^{1}$. Hipertensi merupakan kondisi tekanan darah di arteri meningkat, peningkatan ini menyebabkan jantung harus bekerja lebih dari biasanya untuk mengedarkan darah melalui pembuluh darah. Tekanan darah melibatkan dua pengukuran yaitu sistolik dan diastolik. Tekanan darah normal pada saat istirahat adalah dalam kisaran sistolik 100-140 mmHg dan diastolik 60-90 mmHg. Tekanan darah tinggi terjadi bila tekanan darah terus-menerus berada pada 140/90 $\mathrm{mmHg}$ atau lebih².

Kasus hipertensi menempatkan Provinsi Daerah Istimewa Yogyakarta (DIY) pada urutan ke-5 sebagai provinsi dengan kasus hipertensi yang tinggi di Indonesia, pada tahun 2013 hipertensi di DIY mencapai $35,8 \%$, lebih tinggi jika dibandingkan dengan angka nasional yaitu $31,7 \%$. Hipertensi selalu masuk dalam 10 besar penyakit sekaligus 10 besar penyebab kematian di DIY selama beberapa tahun terakhir. Kabupaten Bantul merupakan salah satu kabupaten yang berkontribusi terhadap kasus hipertensi di DIY. Hipertensi termasuk dalam sepuluh besar penyakit di Kabupaten Bantul, dimana pada tahun 2016 di Kabupaten Bantul sebanyak 44.947 kasus dari seluruh wilayah Kecamatan yang berada di Kabupaten Bantul ${ }^{3}$.

Imogiri merupakah salah satu desa di Kabupaten Bantul, yang berada di daerah binaan Puskesmas Imogiri I. Salah satu daerah binaan Puskesmas Imogiri I adalah Desa Wukirsari. Desa Wukirsari merupakan salah satu desa yang terletak di Kecamatan Imogiri yang mempunyai wilayah seluas 15.385.504 Ha dengan jumlah penduduk \pm 17.245 jiwa. Desa Wukirsari mempunyai 16 pedukuhan antara lain Singosaren, Bendo, Mangung, Tilaman, Pundung, Kedung Buweng, Karang Kulon, Giriloyo, Cengkehan, Nogosari I, Nogosari II, Karangasem, Jatirejo, Karangtalun dan Dengkeng. Berdasarkan wawancara dengan Kepala Puskesmas Imogiri I, penderita hipertensi yang rutin kontrol ke Puskesmas Imogiri I dan bertempat tinggal di Desa Wukirsari sejumlah 97 orang.

Posyandu Mawar Agung merupakan posyandu di lingkungan Desa Wukirsari, Imogiri, Bantul, DIY. Aktivitas posyandu ini dilakukan satu bulan sekali, di minggu kedua setiap bulannya. Akan tetapi saat ini, aktivitas posyandu menjadi pasif dikarenakan banyak kader posyandu yang sudah pernah ikut 


\section{Jurnal Pelayanan dan Pengabdian Masyarakat (PAMAS)}

berbagai pelatihan dari puskesmas, berpindah tempat tinggal. Padahal mayoritas masyarakat berusia produktif yaitu 18-59 tahun, yang berpotensi dan dapat diberikan program kaderisasi dan pemberdayaan agar menguatkan dan mengoptimalkan peran posyandu di masyarakat. Posyandu merupakan salah satu bentuk Upaya Kesehatan Bersumberdaya Masyarakat (UKBM) yang dikelola dari, oleh, untuk, dan bersama masyarakat, guna memberdayakan masyarakat dan memberikan kemudahan kepada masyarakat dalam memperoleh pelayanan kesehatan dasar. Upaya peningkatan peran dan fungsi posyandu bukan semata-mata tanggung jawab pemerintah saja, namun semua komponen yang ada di masyarakat, termasuk kader kesehatan. Peran kader kesehatan dalam penyelenggaraan posyandu sangat besar karena selain sebagai pemberi informasi kesehatan kepada masyarakat juga sebagai penggerak masyarakat untuk datang ke posyandu dan melaksanakan perilaku hidup bersih dan sehat ${ }^{4}$.

Berdasarkan data yang dikelola oleh Posyandu Mawar Agung, cukup banyak warga Desa Wukirsari yang menderita tekanan darah tinggi, dari keseluruhan warga Desa Wukirsari, sejumlah 97 orang (40\%) sudah terdeteksi menderita hipertensi, bahkan sudah ada 5 (lima) orang warga yang terserang komplikasi hipertensi yaitu menderita penyakit stroke dan saat ini mengalami hambatan mobilitas fisik dan tergantung dengan orang lain/keluarga serta mengganggu aktivitas perekonomian keluarga. Tingkat pendidikan masyarakat di Desa Wukirsari tidak semua mengenyam pendidikan tinggi, mayoritas lulusan SD/SMP. Mayoritas pekerjaannya adalah petani, pekerja buruh, pengayuh becak, Ibu Rumah Tangga (IRT), tukang tambal ban, kuli gendong di pasar, maupun pemulung.

Berdasarkan hasil wawancara dengan penderita hipertensi dan keluarganya, dapat disimpulkan bahwa mereka kurang terpapar informasi tentang kesehatan, tidak mengetahui berapa batasan tekanan darah normal dan tidak normal, tidak mengetahui apa saja faktor risiko hipertensi, tidak dapat mengukur tekanan darah sendiri di rumah, dan tidak mengetahui bahaya komplikasi hipertensi. Posyandu Mawar Agung ini pernah mendapatkan bantuan alat kesehatan berupa 2 (dua) buah stetoskop dan 2 (dua) buah spignomanometer dari Puskesmas Imogiri I, namun alat tersebut tidak terpakai karena pengurus posyandu ataupun masyarakat di lingkungan tersebut tidak bisa mempergunakan alat tersebut dan kader posyandu terlatih sudah berpindah tempat tinggal. Berdasarkan latar belakang tersebut, penulis melakukan kegiatan pengabdian kepada masyarakat dengan memberikan pelatihan C-E-R-A-M-A-H yaitu pelatihan "Cek Tekanan Darah di Rumah" bagi penderita hipertensi dan kader kesehatan di lingkungan Desa Wukirsari, sebagai upaya preventif hipertensi dan juga menghindari hipertensi tidak terkontrol sehingga kegiatan ini diharapkan dapat sebagai upaya pengendalian penyakit hipertensi di komunitas. 


\section{METODE}

\section{a. Tahap Persiapan}

Tahap persiapan dari kegiatan pengabdian kepada masyarakat ini adalah 1) penyusunan proposal kegiatan pengabdian kepada masyarakat, 2) penyusunan angket/kuesioner untuk mengetahui bagaimana pemahaman penderita hipertensi dan kader kesehatan, sebelum dan sesudah diberikan pelatihan, serta 3) penyusunan dan penyiapan media pelatihan dalam bentuk booklet. Tahap persiapan dimulai pada Bulan Agustus 2020. Kegiatan pengabdian kepada masyarakat ini didahului dengan studi pendahuluan melalui metode wawancara dengan pihak Puskesmas Imogiri I, Kelurahan Wukirsari dan pengelola Posyandu Mawar Agung. Selanjutnya, penulis melakukan kegiatan FGD (Focuss Group Discussion) persiapan pelaksanaan kegiatan pengabdian kepada masyarakat bersama dengan mitra. Hasil FGD tersebut dituangkan dalam PoA (Plan of Action), yang disusun bersama oleh pengusul dan pihak mitra. Setiap kegiatan disusun secara detail dalam PoA, mencakup 1) apa yang dikerjakan (persiapan dan pelaksanaan), 2) tujuan dan sasaran, 3) jadwal kegiatan, 4) tempat pelaksanaan, 5) unit/siapa yang bertanggungjawab/melaksanakan, dan 6) jumlah dan sumber anggaran. PoA ini disepakati saat FGD Persiapan Pelaksanaan Program PKM.

\section{b. Tahap Pelaksanaan}

Pelaksanaan kegiatan pengabdian kepada masyarakat ini dilaksanakan pada Bulan September 2020. Sebelum pelatihan dilaksanakan, mitra ikut berpartisipasi dalam penyusunan Term of Reference (TOR) kegiatan. Pengurus RT dan atau pengurus posyandu terlibat sebagai fasilitator pada pelatihan ini sekaligus sebagai asisten kegiatan pengabdian pada kegiatan door to door. Pelatihan ini diberikan dalam bentuk ceramah dan praktik. Pada tahap awal dilakukan pretest dan di akhir juga dilakukan posttest. Jumlah kader posyandu 12 orang yang mengikuti kegiatan ini sedangkan jumlah penderita hipertensi 40 orang yang ikut serta dalam kegiatan ini. Materi-Materi dalam pelatihan ini akan diberikan dalam bentuk "Booklet C-E-R-A-M-A-H". Booklet tersebut berisikan materi-materi antara lain : a) pengertian hipertensi, b) faktor risiko hipertensi, c) bahaya dan komplikasi hipertensi tidak terkontrol, d) tujuan dan manfaat pengukuran tekanan darah di rumah secara rutin, e) alat dan bahan yang diperlukan saat pengukuran tekanan darah di rumah, dan f) persiapan yang perlu dilakukan sebelum pengukuran tekanan darah di rumah.

Pelatihan C-E-R-A-M-A-H bagi kader kesehatan posyandu dilakukan di Balai Desa Wukirsari sedangkan pelatihan C-E-R-A-M-A-H bagi penderita hipertensi beserta keluarganya dilakukan door to door di rumah masing-masing dengan mempertimbangkan aspek bahwa penderita 
hipertensi merupakan kelompok risiko tinggi atau komorbid dari penularan Covid-19. Akibat pandemi Covid-19, kegiatan pelatihan C-E-R-A-M-AH ini dilakukan dengan mematuhi protokol kesehatan, seluruh penderita hipertensi beserta keluarganya dan kader kesehatan posyandu yang ikut serta dalam pelatihan ini wajib menggunakan masker, mencuci tangan dengan sabun dan air mengalir serta menjaga jarak minimal 1 meter. Pada kegiatan ini, seluruh penderita hipertensi serta keluarganya dan kader kesehatan posyandu juga dilakukan pengukuran suhu dengan thermogun dengan parameter suhu tubuh normal yaitu $36,5-37,5^{\circ} \mathrm{C}$.

\section{HASIL DAN PEMBAHASAN}
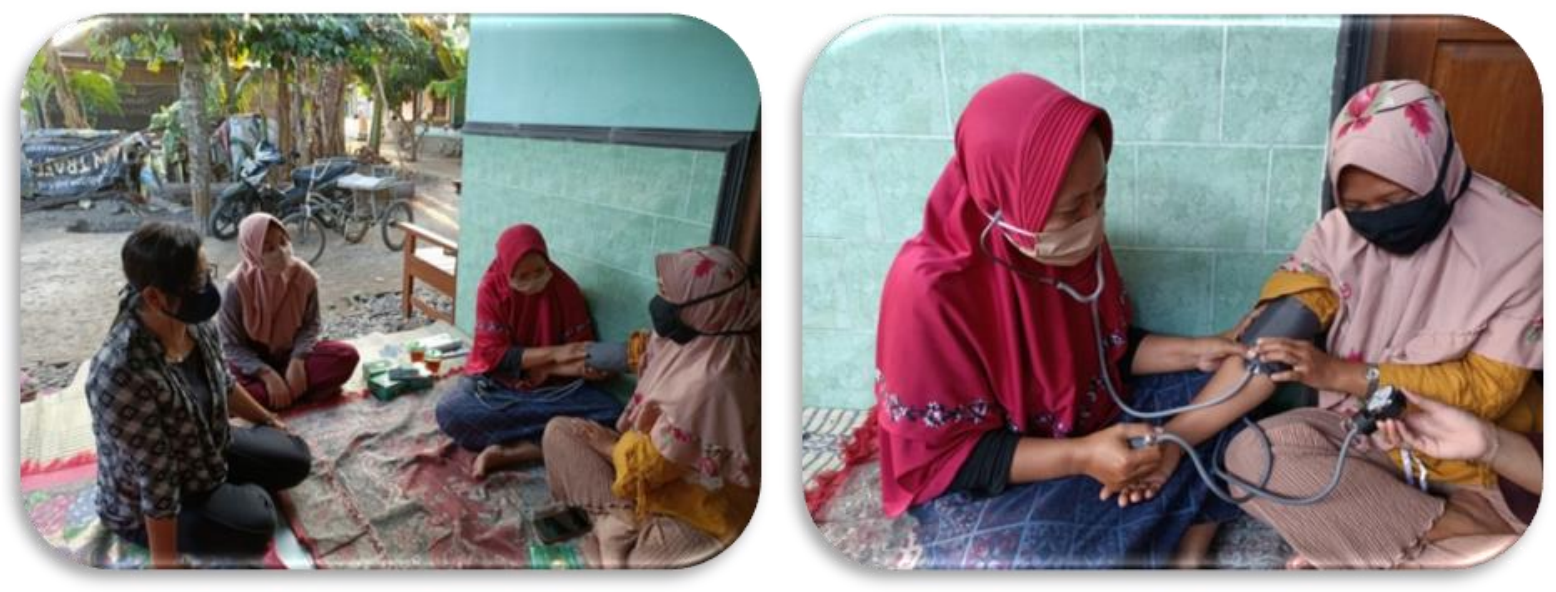

Gambar a. Kegiatan Kader Kesehatan Posyandu dalam Pelatihan C-E-R-A-M-A-H

Kegiatan pengabdian kepada masyarakat dengan judul "Optimalisasi Pemberdayaan Masyarakat melalui Strategi Pelatihan C-E-R-A-M-A-H sebagai Upaya Pengendalian Penyakit Hipertensi di Komunitas" ini mengelompokkan sasaran kegiatan menjadi dua, yaitu 1) kader kesehatan posyandu dan 2) penderita hipertensi yang rutin kontrol di Puskemas Imogiri I yang bertempat tinggal di Desa Wukirsari beserta keluarganya.
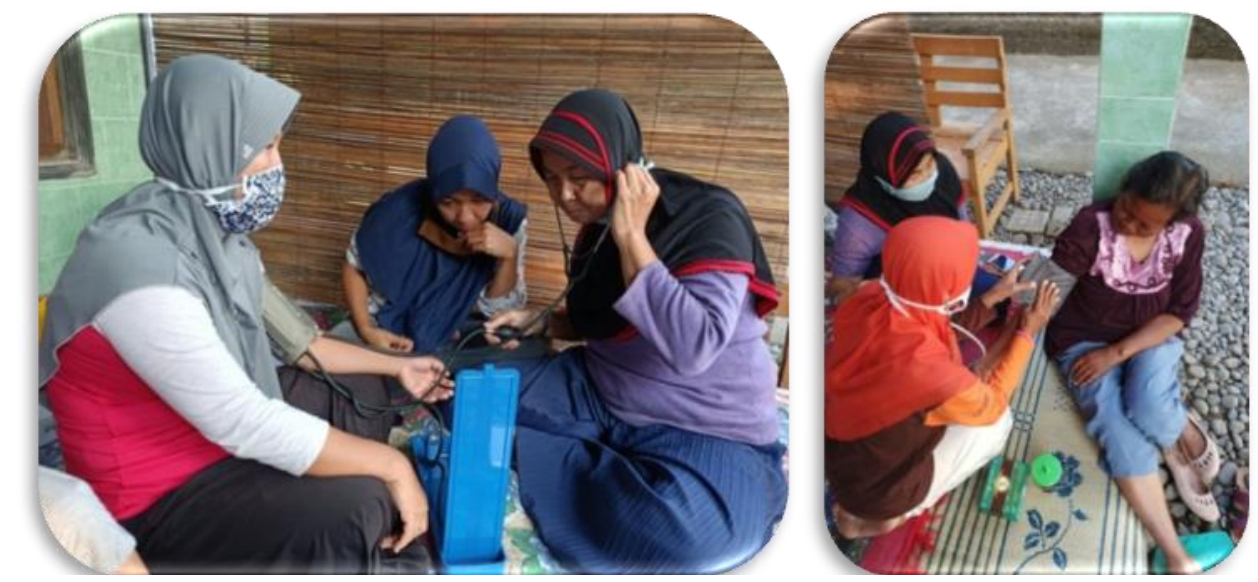

Gambar b. Kegiatan peer teaching saat praktik pengukuran tekanan darah 
Jurnal Pelayanan dan Pengabdian Masyarakat (PAMAS)

Sasaran kegiatan yang pertama yaitu pelatihan C-E-R-A-M-A-H bagi kader kesehatan posyandu. Pada tahap awal dilakukan pretest terlebih dahulu, bertujuan untuk mengetahui bagaimana tingkat pemahaman kader kesehatan posyandu tentang praktik pengukuran tekanan darah di rumah. Hasil pretest menunjukkan yaitu hanya 2 dari 10 orang kader kesehatan posyandu yang memperoleh nilai/skor kategori baik (> 80). Rata-rata nilai/skor pretest adalah $\pm 43,69 \%$. Pada kegiatan ini, hasil pretest dikelompokkan menjadi 3 kategori yaitu kategori rendah $(<60)$, kategori cukup (60-80) dan kategori baik (> 80). Mayoritas kader posyandu belum dapat melakukan praktik pengukuran tekanan darah. Tahap selanjutnya adalah penyampaian materi tentang pelatihan C-E-R-A-M-AH. Kader kesehatan posyandu diberikan "Booklet C-E-R-A-M-A-H". Booklet tersebut mencakup materi-materi antara lain : a) pengertian hipertensi, b) faktor risiko hipertensi, c) bahaya dan komplikasi hipertensi tidak terkontrol, d) tujuan dan manfaat pengukuran tekanan darah di rumah secara rutin, e) alat dan bahan yang diperlukan saat pengukuran tekanan darah di rumah, dan f) persiapan yang perlu dilakukan sebelum pengukuran tekanan darah di rumah. Penyampaian materi tentang pelatihan C-ER-A-M-AH ini juga melibatkan pihak Puskesmas Imogiri I.
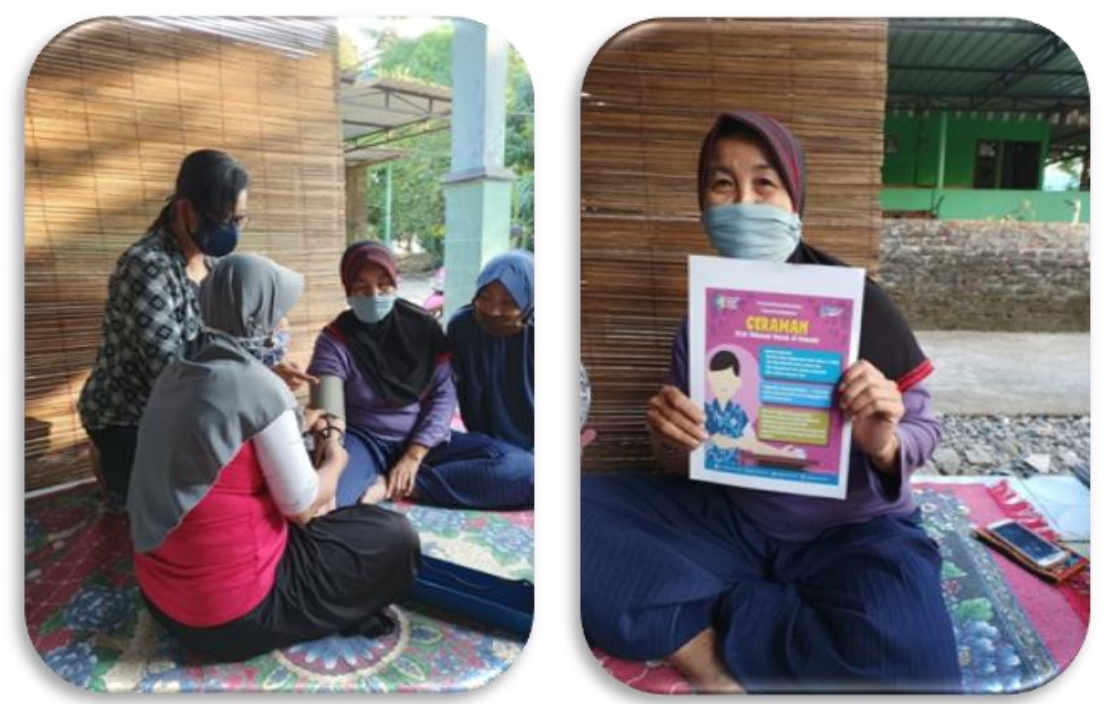

Gambar c. Kader kesehatan posyandu mengikuti pelatihan dengan media booklet C-E-R-A-M-AH

Pada tahap akhir, diperoleh hasil posttest yaitu 12 orang kader posyandu dapat melakukan praktik pengukuran tekanan darah di rumah dengan benar, baik dengan pendampingan maupun mandiri. Rata-rata nilai/skor posttest adalah $\pm 87,46 \%$. Berdasarkan perbandingan nilai/skor hasil pretest dan posttest tersebut dapat disimpulkan bahwa terdapat peningkatan pemberdayaan mitra yaitu tingkat pengetahuan dan ketrampilan kader posyandu tentang praktik pengukuran tekanan darah di rumah meningkat. 

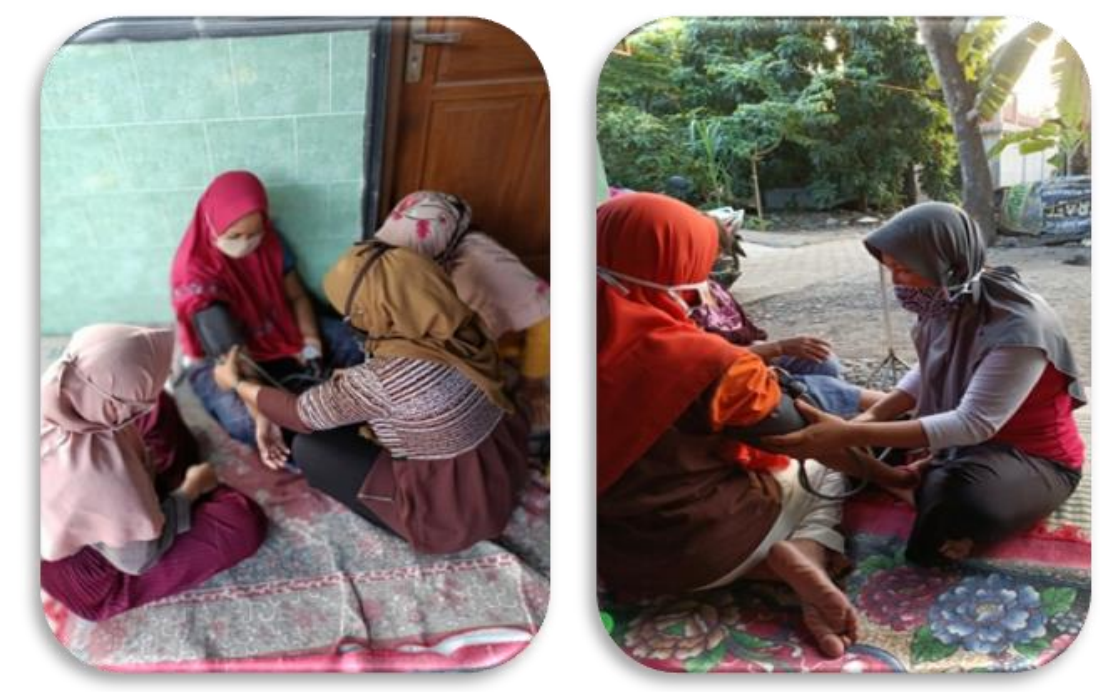

Gambar d. Kader posyandu antusias ikut serta dalam pelatihan C-E-R-A-M-A-H

Sasaran kegiatan yang kedua yaitu penderita hipertensi yang rutin kontrol di Puskemas Imogiri I yang bertempat tinggal di Desa Wukirsari beserta keluarganya. Hasil pretest menunjukkan yaitu hanya 7 dari 40 orang penderita hipertensi beserta keluarganya yang memperoleh nilai/skor kategori baik $(>80)$. Rata-rata nilai/skor pretest adalah $\pm 47,81 \%$. Pada kegiatan ini, hasil pretest dikelompokkan menjadi 3 kategori yaitu kategori rendah $(<60)$, kategori cukup (60-80) dan kategori baik (> 80). Mayoritas penderita hipertensi beserta keluarganya belum dapat melakukan praktik pengukuran tekanan darah. Tahap selanjutnya adalah penyampaian materi tentang pelatihan C-E-RA-M-AH. Penderita hipertensi beserta keluarganya diberikan "Booklet C-E-R-A-M-A-H". Booklet tersebut mencakup materi-materi antara lain : a) pengertian hipertensi, b) faktor risiko hipertensi, c) bahaya dan komplikasi hipertensi tidak terkontrol, d) tujuan dan manfaat pengukuran tekanan darah di rumah secara rutin, e) alat dan bahan yang diperlukan saat pengukuran tekanan darah di rumah, dan f) persiapan yang perlu dilakukan sebelum pengukuran tekanan darah di rumah. 


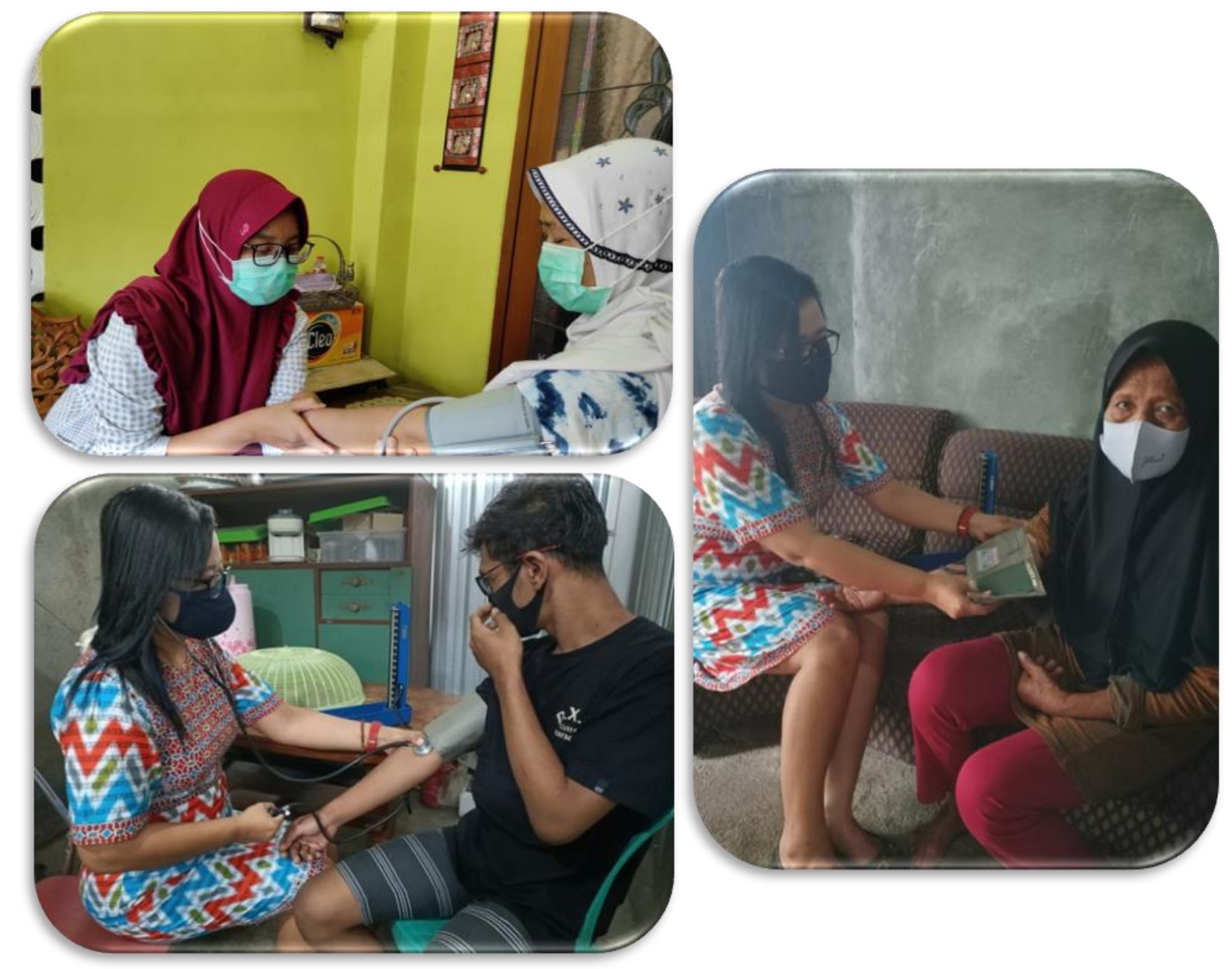

Gambar e. Pelatihan C-E-R-A-M-AH pada penderita hipertensi beserta keluarganya

Pada tahap akhir, diperoleh hasil posttest yaitu 40 orang penderita hipertensi dan keluarganya dapat melakukan praktik pengukuran tekanan darah di rumah dengan benar, baik dengan pendampingan maupun mandiri. Rata-rata nilai/skor posttest adalah $\pm 82,76 \%$. Berdasarkan perbandingan nilai/skor hasil pretest dan posttest tersebut dapat disimpulkan bahwa terdapat peningkatan pemberdayaan mitra yaitu tingkat pengetahuan dan ketrampilan penderita hipertensi dan keluarganya tentang praktik pengukuran tekanan darah meningkat.

\section{KESIMPULAN}

Pelatihan C-E-R-A-M-AH merupakan wujud optimalisasi pemberdayaan masyarakat sebagai upaya pengendalian penyakit hipertensi di komunitas. Pelatihan C-E-R-A-M-AH merupakan strategi meningkatkan tingkat pengetahuan dan ketrampilan, baik bagi kader kesehatan posyandu dan juga penderita hipertensi beserta keluarganya tentang praktik pengukuran tekanan darah di rumah. Selain itu, pelatihan C-E-R-A-M-AH juga meningkatkan pemahaman kader kesehatan posyandu dan 
juga penderita hipertensi beserta keluarganya tentang a) pengertian hipertensi, b) faktor risiko hipertensi, c) bahaya dan komplikasi hipertensi tidak terkontrol, d) tujuan dan manfaat pengukuran tekanan darah di rumah secara rutin, e) alat dan bahan yang diperlukan saat pengukuran tekanan darah di rumah, dan f) persiapan yang perlu dilakukan sebelum pengukuran tekanan darah di rumah. Pelatihan C-E-R-A-M-AH dapat diprioritaskan sebagai program rutin dan berkala di masyarakat sehingga angka kejadian hipertensi dalam diminimalkan dan bahaya serta komplikasi akibat hipertensi dapat dicegah.

\section{DAFTAR PUSTAKA}

World Health Organization (WHO). 2019. Hypertension. Dikutip dari : https://www.who.int/newsroom/fact-sheets/detail/hypertension.

Departemen Kesehatan RI. 2018. Indonesia Health Profile Year 2017. Jakarta: Ministry Health RI.

Departemen Kesehatan RI. 2017. Profil Kesehatan Provinsi Daerah Istimewa Yogyakarta Tahun 2017. Jakarta: Kementerian Kesehatan RI.

Departemen Kesehatan RI. 2012. Kurikulum dan Modul Pelatihan Kader Posyandu. Jakarta: Kementerian Kesehatan RI bekerja sama dengan Pokjanal Posyandu Pusat. 